\section{Correlation between interalar width and intercommissural width toward mesiodistal width of upper central incisor of buton tribe}



CrossMark

\author{
Bahruddin Thalib," Lenny Alvionita
}

\title{
Abstract
}

Objective: Different facial anatomy landmark is influenced by age, gender, region of residence and origin of his or her tribe. Tribe or race is a race classification based on physical characteristics, such as face shape, hair and skin color. This study was to evaluate the correlation between interalar width and intercommissural width against mesiodistal incisivus centralis width in a group of Buton tribe.

Material and Methods: Ninety five Buton tribe subjects aged 17-25 were selected. The interalar width, intercommissural width and mesiodistal incisor centralis teeth were measured using caliper about three times for accuracy and precision.

Results: The degree of correlation between interalar width against mesiodistal incisor centralis maxilla width was 0.278 and 0.325 in
Buton tribe and females $(p<0.05)$ and 0.168 in males $(p>0.05)$. The degree of correlation between intercommissural width against mesiodistal incisor centralis maxilla width was 0.310 and 0.420 in Buton tribe and females $(p<0.05)$ and 0.125 in males $(p>0.05)$. The degree of correlation between interalar width against intercommissural width was $0.565,0.585$ and 0.455 in Buton tribe, males and females $(p<0.05)$.

Conclusion: There is a significant correlation between interalar width and intercommissural width against mesiodistal incisor centralis maxilla width in a group of Buton tribe. Interalar width and intercommissural width was directly proportional to mesiodistal incisor centralis maxilla width in both the gender of Buton tribe.
Department of Prosthodontic, Faculty of Dentistry, Hasanuddin University, Makassar, Indonesia
*Correspondence to: bathalib64@yahoo.com

Received: 28 January 2016

Revised: 25 April 2016

Accepted: 26 April 2016

Available Online: 30 April 2016

Keywords: Interalar width, Intercommissural width, Mesiodistal incisivus centralis, Maxilla width, Buginese tribe Cite this Article: Thalib B, Alvionita L. 2016. Correlation between interalar width and intercommissural width toward mesiodistal width of upper central incisor of buton tribe. Journal of Dentomaxillofacial Science 1(1): 53-57. D0I:10.15562/jdmfs.v1i1.26

\section{Introduction}

Mesiodistal tooth width of each individual is different, every population is also different with other population. Mesiodistal width data of the teeth is an important information prior to a treatment in dentistry primarily in the areas of conservation, Orthodontists, Forensic and Prosthodontics. Mesiodistal width variation is due to the influence of race, genetic, environmental, ethnic, gender and disease. Various types of facial anatomy landmarks which must have an appropriate proportion to the size of the tooth are interalar width, intercommissural width, interpupillary width, intercanthal width and bizygomatic width. Some facial landmarks can be used as a guide in the selection of anterior teeth in the manufacture of a full denture, especially when recording pre-extraction photos like teeth photos, teeth that have been uprooted, study models, remaining teeth, face shape and the shape of the arch that has been lost. ${ }^{1,2}$

Different facial anatomy landmark is influenced by age, gender, region of residence and origin of his tribe. Tribe or race is a classification based on physical characteristics, such as face shape, hair and skin color. The tribes who originally inhabited the Southeast Sulawesi namely: Tolaki tribe, Muna tribe and Buton tribe. All three of these tribes have typical anatomical landmarks. ${ }^{3}$

There have been many researches done to determine the relationship between the anatomical structure and characteristics of the patient's face shape or size of the teeth. Starting from interpupil width measurements (width between the pupils), intercanthal wide, bizygomatic width, interalar width (width of the base of the nose) and intercommissural width (width of mouth). ${ }^{4,5}$

From several methods of measurement, measurement of interalar width (width of the base of the nose) and intercommissural width (widemouth) is a measurement that performed closest to the anterior maxilla, so researchers were interested to find out the comparison between these two measurement in their relationship with mesiodistal tooth width of upper right central incisor on Buton tribe.

\section{Material and Methods}

This study was an observational analytical study with nonexperimental correlational design. This study took place on April, 2015 in Murhum, Bau-Bau. Study samples were the residents of 
Murhum District, Bau-Bau City with the age range of 17-25 years old and sample selection was based on specific criteria. Total study samples were 95 people.

We used caliper, stationery, cotton/tissue and alcohol. Subjects who have met the study criteria were given a description of study procedures and then asked to sign an informed consent. Then we measured interalar width on the subject as much as three times repetition, measured intercommissural width for three times and measured the mesiodistal width of upper central incisor as many as three times. Further we recorded measurement data.

\section{Results}

We had carried out a study on the relationship of the interalar width and intercommissural width against mesiodistal width of upper central incisor on Buton tribe. This study was an observational analytical study with non-experimental correlation design. April 2015 was the time of the study and took place in the District Murhum, Bau-Bau. Samples were resident in the region. Based on the formula of the samples, the number of samples

Table 1 Age distribution of study sample

\begin{tabular}{lcccc}
\hline \multicolumn{1}{l}{ Age category } & Frequency & Percentage & $\begin{array}{c}\text { Cumulative } \\
\text { percentage }\end{array}$ \\
\hline Valid & 15-19 years old & 66 & 69.5 & 69.5 \\
& $20-24$ years old & 20 & 21 & 21 \\
25-29 years old & 9 & 9.5 & 9.5 \\
& Total & 95 & 100.0 & \\
\hline
\end{tabular}

\section{Table 2 Measurement comparison of each variable in male and} female

\begin{tabular}{lccc}
\hline Variable & Male $(\mathbf{n}=\mathbf{4 2})$ & Female $(\mathbf{n}=53)$ & $\boldsymbol{P}$ value \\
\hline Interalar width & $36.64 \pm 2.42$ & $34.89 \pm 2.65$ & 0.001 \\
Intercommissural width & $45.42 \pm 2.95$ & $43.09 \pm 3.09$ & 0.000 \\
Mesiodistal width of upper & $4.29 \pm 0.91$ & $4.09 \pm 0.92$ & 0.318 \\
central incisor & & & \\
\hline
\end{tabular}

Table 3 Relationship between interalar width and mesiodistal width of upper central incisor

\begin{tabular}{lccc}
\hline & $\begin{array}{c}\text { Pearson } \\
\text { Correlation }(\mathbf{r})\end{array}$ & P value & Result \\
\hline Total $(\mathrm{n}=95)$ & 0.278 & 0.006 & Significant \\
Male $(\mathrm{n}=42)$ & 0.168 & 0.288 & Not significant \\
Female $(\mathrm{n}=53)$ & 0.325 & 0.018 & Significant \\
\hline
\end{tabular}

in this study was 95 samples, which consisted of 42 men and 53 women. The data obtained from study were processed using SPSS 18.

Table 1 shows the result that the average age of patients in the study sample was within age range $15-19$ years as many as 66 people $(69.5 \%)$, 20-24 years as many as 20 people $(21 \%)$ and $25-29$ years as many as 9 people (9.5\%).

Table 2 shows that the average interalar width in male were $36.64 \pm 2.42 \mathrm{~mm}$ and significantly wider than female which was $34.89 \pm 2.65 \mathrm{~mm}$ $(p<0.05)$. While the average intercommissural width was significantly wider in male $45.42 \pm$ 2.95 , it was $43.09 \pm$ wider than female 3.09 $(\mathrm{p}<0.05)$. The average width of the central incisor mesiodistal in the male $4.29 \pm 0.91 \mathrm{~mm}$ was significantly higher than females $4.09 \pm 0.92 \mathrm{~mm}$ $(\mathrm{p}>0.05)$.

Based on the results obtained on table 3 the relationship of interalar width and mesiodistal width of upper central incisor on Buton tribe were 0.006 . That was, $0.006<0.05$ which means the correlation between two variables were significant and their relationship was in positive direction $(\mathrm{r}=0.278)$. The tables also showed that male was 0.288 means $0.288>0.05$ and thus the correlation between the two variables were not significant and with the positive direction $(\mathrm{r}=0.168)$. As for the female it was 0.018 . This means that $0.018>0.05$ and thus the correlation between the two variables was significant and its relationship in the positive direction $(\mathrm{r}=0325)$.

The table 4 shows that relationship between intercommissural width and mesiodistal width of upper central incisor on Buton tribe was 0.002. It means, $0.002<0.05$, thus the correlation between those two variables were significant and their relationship was in the positive direction $(\mathrm{r}=0.310)$. The tables also showed that on male was 0.432 . This means that $0.432>0.05$, thus the correlation between the two variables was also not significant and weak with the positive direction $(\mathrm{r}=0.125)$. As for the female it was 0.002 . This means that $0.002>0.05$, and thus a significant correlation between those two variables and the relationship was also in the positive direction $(\mathrm{r}=0.420)$

The table 5 shows relationship between interalar width and intercommissural width on Buton Tribe was 0.000 . That is, $0.000<0.05$, thus the correlation of those two variables were significant and strong with the positive direction $(\mathrm{r}=0.565)$. The tables also showed that in males was 0.000 . This means $0.000>0.05$ and thus the correlation between the two variables is also significant and strong relationship with the positive direction $(\mathrm{r}=0.585)$. As for the female was 0.001 . This means that $0.001>0.05$ and thus the correlation between the two variables 
Table 4 Relationship between intercommissural width and mesiodistal width of upper central incisor

\begin{tabular}{lccc} 
& $\begin{array}{c}\text { Pearson } \\
\text { correlation }(\mathbf{r})\end{array}$ & p-value & Result \\
\hline Total $(\mathrm{n}=95)$ & 0.310 & 0.002 & Significant \\
Male $(\mathrm{n}=42)$ & 0.125 & 0.432 & Not significant \\
Female $(\mathrm{n}=53)$ & 0.420 & 0.002 & Significant \\
\hline
\end{tabular}

Table 5 Relationship between interalar width and intercommissural width

\begin{tabular}{lccc}
\hline & Pearson correlation $(\mathbf{r})$ & $p$-value & Result \\
\hline Total $(\mathrm{n}=95)$ & 0.565 & 0.000 & Significant \\
Male $(\mathrm{n}=42)$ & 0.585 & 0.000 & Significant \\
Female $(\mathrm{n}=53)$ & 0.455 & 0.001 & Significant \\
\hline
\end{tabular}

were also significant with the positive direction $(\mathrm{r}=0.455)$

\section{Discussion}

Guidelines that can be used to select the anterior teeth of dentures are instructions before extraction, shapes, textures, colors, materials, dentogenic concepts and size. The size of the anterior teeth is one of the important factors to meet the aesthetic for anterior teeth of the upper jaw that will be seen when the patient is talking or laughing. ${ }^{2}$

One of the aesthetic principles in determining the size of the anterior teeth is the tooth width. Some guidelines that may assist dentists in determining the width of the anterior teeth of the upper jaw is instructions before extraction include: facial images, diagnostic model, dental radiography, dental kin and teeth that had been removed. If the instructions before extraction are not obtained, then the doctor can use the face as measurement guidelines include bizygomatic width, intercommissural width, interpupillary width, lateral surface of nose, cranial circumference and incisive papilla. ${ }^{13}$

Facial anatomy landmark studied in this research was interalar width and intercommissural width, because nose, mouth and teeth evolved from a similar tissue which is derived from the facial processes. This study was conducted to determine the relationship between interalar width and intercommissural width toward mesiodistal width of upper central incisor of Buton Tribe.

The subjects of this study were descendant from Buton tribe for three generations. Both the parents and the grandparents from both sides of the subjects were from Buton tribe for three generations. This is based on Mendel's First Law (Law of Segregation) which stated "Two members of a gene pair divide to form gametes, so that one part of the gametes carry one member of the gene and the other gamete carrying another gene".
In broad term, the purpose of Mendel's First Law is that the first gene has alternative forms of governing variations on the character of its derivatives. This is the concept of two kinds of alleles: recessive alleles which are not always visible from the outside and the dominant allele that is visible from the outside, Second: each individual carries a pair of genes, one from the male parent and the from the females, Three: If the gene pair is different alleles, dominant allele will always be expressed visually from the outside. From this characteristic, facial profile of a tribe can still be expressed from the outside to the third generation. ${ }^{23,24}$

Facial anatomy landmark studied in this research was interalar width and intercommissural width, because nose, mouth and teeth evolved from a similar tissue which is derived from the facial processes. This study was conducted to determine the relationship between the interalar width and intercommissural width toward mesiodistal width of upper central incisor on Buton Tribe.

The subjects were resident of Murhum Subdistrict, City of Bau-Bau consisted of 95 people. The research sample was 42 male and 53 female. Age distribution was 66 people within age range of 1519 years, 20 people with average of $20-24$ years old and nine people with average of 25-29 years old.

The caliper instruments used in this study was proposed to measure interalar width which is the distance between the outermost points of the "alae nasi" or left and right wings in a relaxed state and not widened. The instrument was also used to measure intercommissural width which is the distance between the two points "cheilion" on both left and right corner of the lips as well as to measure mesiodistal width of right or left upper central incisor on someone. Mesiodistal width of upper central incisor was measured from mesioincisal to distoincisal. All variables were measured three times and then averaged as the aspect of accuracy and precision. ${ }^{14,15}$ Whenever we started to measure the variables that exist in every subject, caliper instruments were sterilized using cotton or tissue with alcohol.

This study showed that the average size of interalar width in men was significantly wider than in women. This is in line with research conducted by Zlataric et al. ${ }^{19}$

The average size of intercommissural width was significantly wider in men than in women. This is in line with the research conducted by Zlataric et al. ${ }^{19}$ It is also in line with research conducted by Esan et al. ${ }^{25}$ stating that the intercommissural width in men was significantly wider than in women.

This study also showed the measurement result of mesiodistal width of upper central incisor in male was significantly wider than in female. This is 
in line with study conducted by Shah et al. ${ }^{20}$ and Tandale et al. ${ }^{21}$

This study also showed relationship between interalar width and intercommissural width toward mesiodistal width of upper central incisor on Buton Tribe in both gender. Based on table 3 the relationship between interalar width and mesiodistal width of upper central incisor on Buton Tribe was moderate in positive direction and significant.

The tables also showed that relationship between interalar width and mesiodistal width of upper central incisor in males were not significant and weak with the positive direction. It is inversely proportional to the research conducted by Qamar et al. ${ }^{14}$ which stated that the relationship between interalar width and intercanine width was significant and weak with the positive direction. This is because this study only took one element that is central incisor on the left or right. Although the upper central incisor is one of the upper anterior teeth that can be assumed if the width increases, then the distance of intercanine will become wider.

In female, the relationship between interalar width and mesiodistal width of upper central incisor was significant and moderate with positive direction.

The result of this study also showed that the relationship between intercommissural width and mesiodistal width of upper central incisor on Buton Tribe was significant and moderate with positive direction.

The tables also showed that relationship between intercommissural width and mesiodistal width of upper central incisor on male were not significant and weak in positive direction, which means that for every addition to intercommissural width then there will be also an addition to mesiodistal width of upper central incisor on male. It is in line to the research conducted by Hussain et al. ${ }^{24}$ that showed a relationship between intercommissural width and intercanine width was not significant and weak with negative direction.

Further, this study also pointed out that relationship between interalar width and intercommissural width was significant and strong with positive direction, which means that for every addition on interalar width then there will be an addition on intercommissural width of Buton Tribe. As on table 5 , it was obtained that relationship between interalar width and intercommissural width in males were significant and strong with positive direction, which means for every addition on interalar width then there will be an addition toward intercommissural width in males. As on females, we obtained that the relationship between interalar width and intercommissural width were significant and moderate with positive direction.
From the result of this study we can make proportion of interalar width, intercommissural width and mesiodistal width of upper central incisor on Buton tribe that in male 8.540:10.587:1 and in female 8.530:10:535:1. The proportion of interalar width toward intercommissural width was 1:1.240 in male and 1:1.235 in female. This proportion does not correspond with the golden proportion stating that the proportion of interalar width toward intercommissural width was 1:1.618. In this study we also found the proportion between mesiodistal width of upper central incisor toward interalar width was $1: 8.540$ and the proportion between mesiodistal width of upper central incisor and intercommissural width was 1:10.587 in male, while the proportion of mesiodistal width of upper central incisor toward interalar width was 1:8.530 and the proportion between mesiodistal width of upper central incisors to intercommissural width was 1:10.535 in female. This does not correspond to the golden proportion that stated the proportion of mesiodistal width of upper central incisor to interalar width was 1:2.85 and the proportions between mesiodistal width of upper central incisors to intercommissural width was 1:4.618. This is likely due to the subjects of this study using the Mongoloid race whereas previous studies using the Caucasian race as subject.

\section{Conclusion}

There is a significant relationship between interalar width and intercommissural width and mesiodistal width of upper central incisor on Buton Tribe. Interalar width and intercommissural width is proportional toward mesiodistal width of upper central incisor on both gender in Buton Tribe.

\section{Conflict of Interest}

The authors report no conflict of interest.

\section{References}

1. Susilowati, Sulastry. Korelasi antara lebar mesiodistal gigi dengan kecembungan profil jaringan lunak wajah orang buton-makassar. Jurnal Kedokteran Gigi 2007;6: 73.

2. Sutardjo I, Sudarso R. Perbedaan pengaruh ukuran mesiodistal gigi desidui rahang atas terhadap bentuk lengkung dan wajah anak arah lateral anak perempuan suku jawa dengan cina umur 5-6 tahun. J Dent 2003;10: 2.

3. Punagi AQ, Julianita. Analisis fotometrik wajah suku-suku di Sulawesi Selatan dan Sulawesi Barat. Maj Kedokt Indon 2008;58: 370-376.

4. Hossain S, Islam KZ, Islam M. Correlation between maxillary canines and facial anatomical landmarks in a group of Bangladeshi people. City Dental College J 2012;9: 12.

5. Mahdi E. An investigation on cephalometric parameters in Iranian population. J Develop Biol Tissue Eng 2012;4: 9.

6. Zuhdi S. Sejarah Buton yang terabaikan. Jakarta: Raja Grafindo Persada; 2010. p. 35-37.

7. Maula MJ, Rudyansjah T, Prahara H, et al. Kesepakatan tanah Wolio (ideologi kebhinekaan dan eksistensi budaya bahari di Buton). Depok: Titian Budaya; 2011. p. 13-18 
8. Ahmad MM. Mengungkap tabir sejarah spriritual dan metafisika, theokrasi serta monarki parlementer kesultanan Buton. Bogor: Yayasan Jabbal Qubais; 2009. p. 17.

9. Soepardi EA, Iskandar N, Bashiruddin J, Restuti RD. Buku ajar ilmu kesehatan telinga hidung tenggorok kepala \& leher. 6th ed. Jakarta: FKUI; 2010. p. 118-119.

10. Anonim. Anatomi umum \& collifacialis. Makassar: Bagian anantomi Fakultas Kedokteran Universitas Hasanuddin; 2012. p. 98,109 .

11. Nelson SJ, Ash MM. Wheeler's dental anatomy, physiology and occlusion. 9th ed. China: Elsevier; 2010. p. 105.

12. Itjiningsih W. Anatomi Gigi. Jakarta: EGC; 2012.

13. Zarb GA. Boucher's prosthodontic treatment for edentulous patients (buku ajar prostodonti untuk pasien tak bergigi menurut Boucher). Jakarta: EGC; 2002. p. 283-289.

14. Qamar K, Hussain MW, Naeem S. The role of the interalar width in the anterior teeth selection. Pak Oral Dent J 2012;32: 570.

15. Bali P, Singh S, Singh AP, et al. Biometric relationship between inner canthal distance and geometric progression for the prediction of maxillary central incisor width. Indian J Dent Sci 2013;5: 53-56.

16. Nallaswamy D. Textbook of prosthodontic. New Delhi: Jaypee; 2007. p. 7,169.

17. Mahesh, Rao S, Kumar P, Shalini. An in vivo clinical study of facial measurement for anterior teeth selection. Ann Esse Dentist 2012;4: 1-6.

18. Ciortea C. Factorii implicati in analiza estetica s Zonei Frontale Maxilare 2014;60: 35-40.
19. Zlataric DK. Analysis of width/length ratios of normal clinical crowns of the maxillary anterior dentition: correlation between dental proportions and facial measurement. The Inter J Prostho 2007;20: 313-315.

20. Shah SA, Naqash TA, Abdullah S, et al. Significance of intercanthal distance in the selection of width of maxillary anterior teeth size in Kashmiri population: a research. Inter J Health Sci Research 2015;5: 215.

21. Tandale HE, Dange SP, Khalikar AN. Biometric relationship between intercanthal dimension and the widths of maxillary anterior teeth. J Indian Prostho Societ 2007;7: 123-125.

22. Hussain MW, Qamar K, Nacem S. Significance of intercommissural width and anterior teeth selection. Pak Oral Dent J 2013;33: 393-396.

23. Cahyono F. Kombinatorial dalam hukum pewarisan mendel. Makalah II2092 Probabilitas dan Statistik; 2010.

24. Available from: URL: http//id.wikipedia.org/wiki/ Hukum_Pewarisan_Mendel. Accesed September 1, 2015.

25. Esan, Oziegbe, Onapokya. Facial approximation: evaluation of dental and facial proportions with height. African Health Sci 2012;12: 63

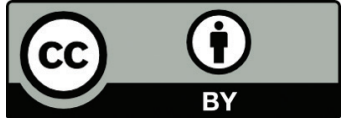

This work is licensed under a Creative Commons Attribution 